\title{
Jules Baillarger \\ and His Discovery of the Six Layers of the Cerebral Cortex
}

\author{
By John F.Fulton, New Haven, Connecticut, U.S.A.
}

Some years ago I contributed a paper to Dr. Sigerist's Bulletin of the Institute of the History of Medicine on Francesco GennarI ${ }^{1,2}$ and his recognition in 1776, confirmed by VIce d'AzYR ${ }^{3}$, of the white line that forms a basic structural element in the occipital cortex-a disclosure of great significance since it marked the beginning of what we now refer to as cortical cytoarchitectonics. After GenNari and VICQ D'AzYR, there was little further attempt to analyze the finer organization of the cerebrum until 1840 when Jules BaILlarger published his memorable paper on the six layers of the cerebral cortex. BAILlARger was an alienist-a psychiatrist who sought through his studies of structure of the cerebral cortex to discover whether or not the mentally deranged showed structural differences from human beings who were mentally normal. At the age of thirty he published his now celebrated memoir, Recherches sur la structure de la couche corticale des circonvolutions du cerveau (Fig. 1) ${ }^{4}$. In his studies herein reported he was disappointed to find that the six basic layers which he had observed in normal brains were also present in the brains of his abnormal patients; however, he did detect profound changes in patients who had suffered from general paralysis.

${ }^{1}$ J.F.Fulton, A note on Francesco Gennari and the early history of cytoarchitectural studies of the cerebral cortex, Bull. Inst. Hist. Med. 5, 895-913 (1937).

${ }^{2}$ F. Gennari, De peculiari structura cerebri nonnullisque ejus morbis. Paucae aliae anatom. observat. accedunt, Parma, Regio Typographeo (Bodoni), 1782. xvi, 87 p., 4 pl.

${ }^{3}$ F. VICQ D'AzYr, Traité d'anatomie et de physiologie, Paris, F. A. Didot, 1786, 3 ll., 123 (1), 111 (1) p., 35 pl. See also: Sur la structure de cerveau, de cervelet, de la moelle alongée, dela moelle épinière; et sur l'origine des nerfs de l'homme et des animaux, Hist. de l'acad. des sci. 1781, p. 495-622, 8 pl.

${ }^{4}$ J.-G.-F. BAILLARger, Recherches sur la structure de la couche corticale des circonvolutions du cerveau, Mém. Acad. Med. Paris, 8, 149-183 (1840) (also reprinted, Paris, J.-B. BAILlère, 1840, 43 p., 2 pl. Although in later life BaIllarger signed himself Jules-GabrieLFrançors BaILlarger, it is curious that in this his first published work he signs himself J.-P. BAILLARGER. This and the writings of J.-G.-F. BAILLARGER are clearly in the same hand so one must either assume that J.-P. was an error of the printer or that he changed his name after 1840. 


\section{RECHERCHES}

SUR LA STRUCTURE

DB LA

\section{COUCHE CORTICALE}

\section{DES CIRCONVOLUTIONS DU CERVEAU,}

PAR M. J.-P. Balllarger,

Doctent en médecine de la Faculté de Paris, ancien premier interne de la maison des aliénés dé Charenton, médecio du bureau de bienfaisance du XI1- arrondissiment, membre de la Sociéte anatomique

PRÉCÉDÉES DU RAPPORT FAIT A L' $A$ CADÉMIE ROYALE DE MÉDECINE, Par MM. RIBES et BLANDIN, rapporteur.

AVEC DEUX PLANCHES.

\section{PARIS ,}

CHEZ J.-B. BAILLIÈRE, LIBRAIRE DE LACADEMIE BOYALE DS.MEDECINE,

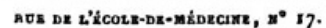

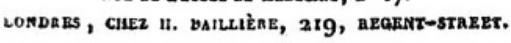

$18 \%$.

Figure 1 


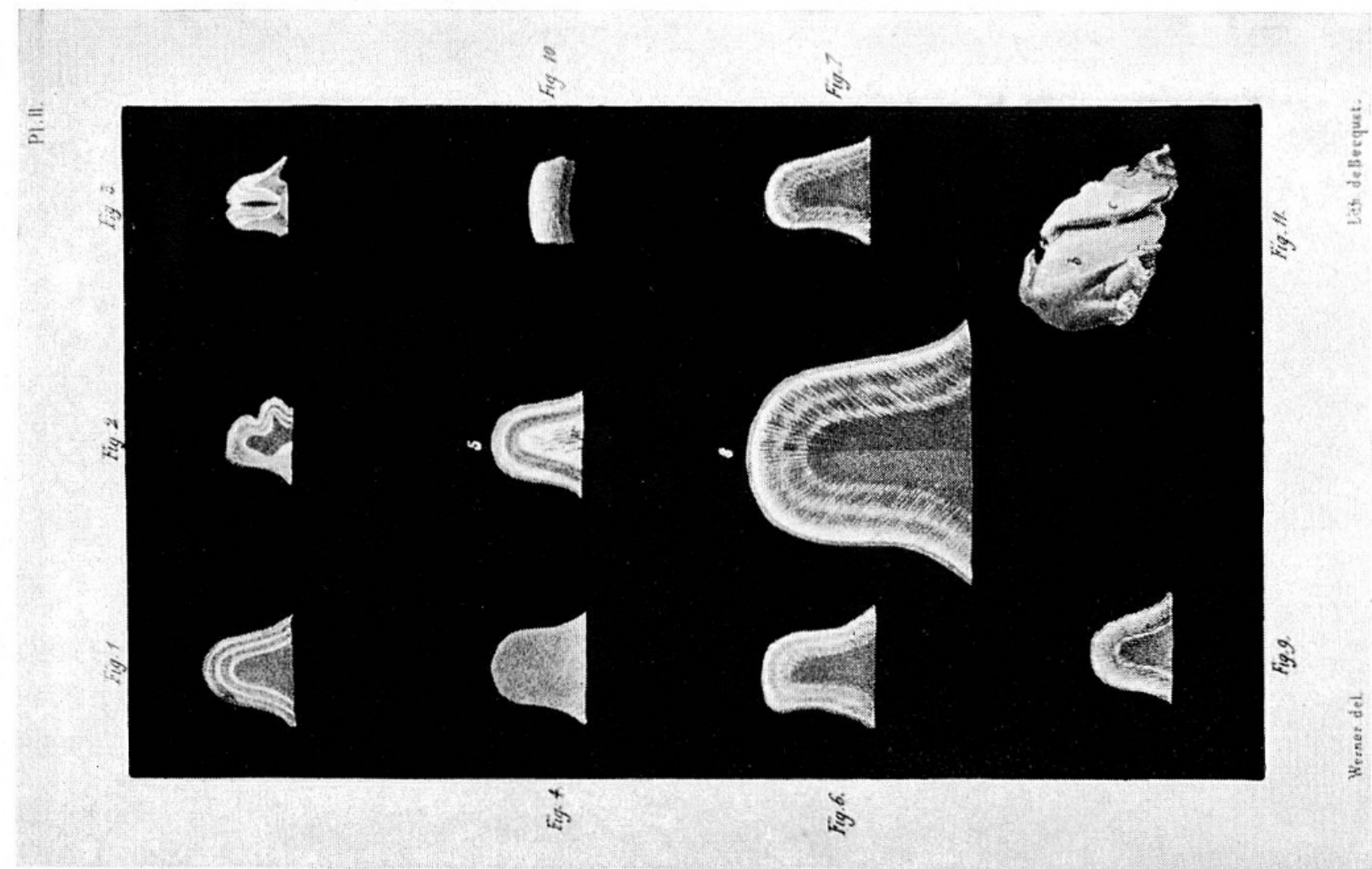

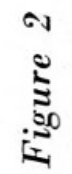

के

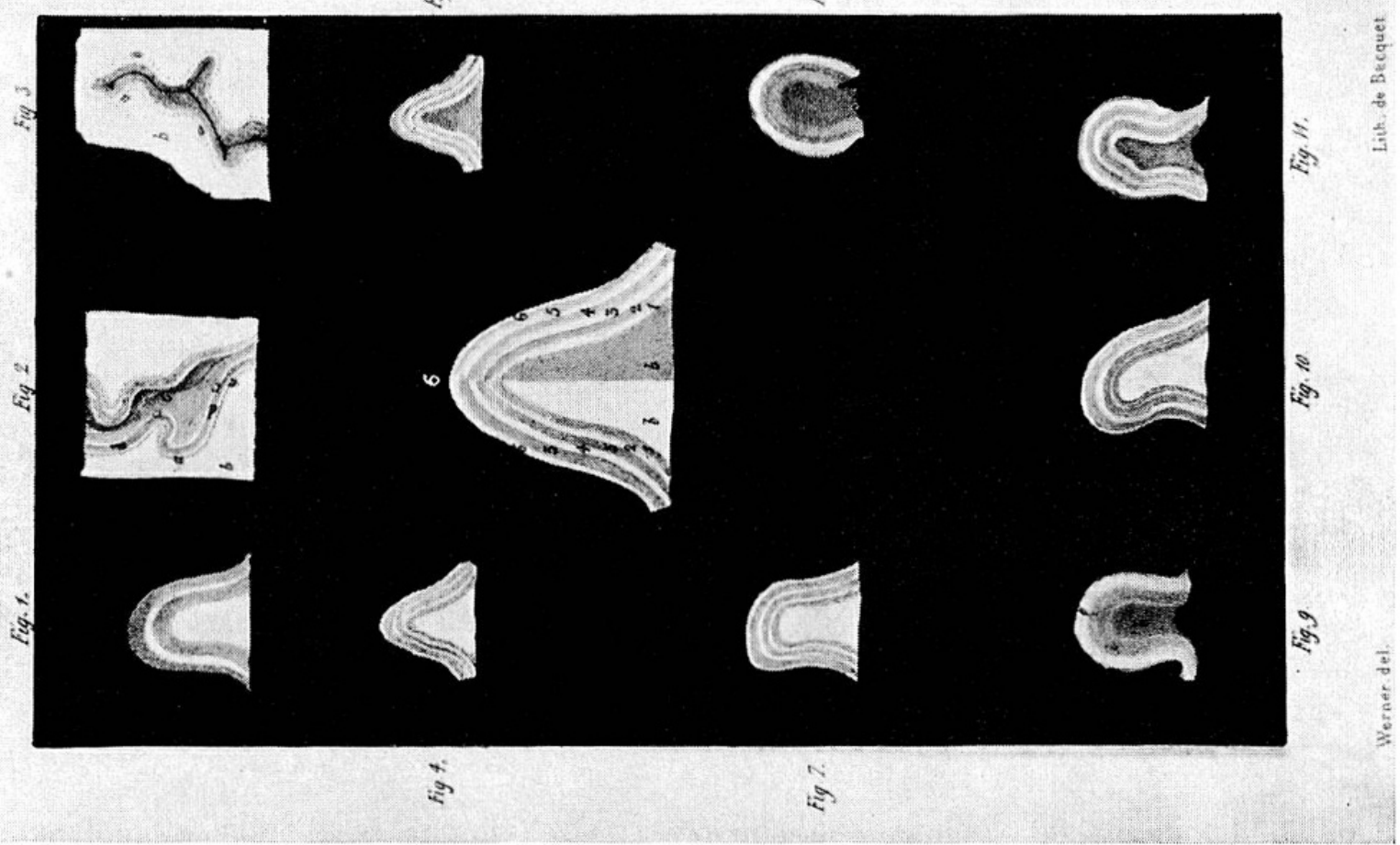


BaILlarger did not have the advantage of a knowledge of cell staining; but he used a microscope to the best of his ability to supplement his gross findings. His major observations were made simply by slicing the cerebral convolutions in thin sections and holding them up to the light between pieces of glass for observation with his unaided eye. By means of this simple procedure he was able to recognize six basic layers of the cerebral cortex. He was aware of the work of Gennari, and the white line which GenNarI had seen in the occipital cortex BAILLARger was able to trace throughout the cerebral mantle with his simple visual technique. I reproduce herewith the two plates which BaILlarger published in his report of 1840 (Fig. 2); also the title-page of the memoir reprinted from the Mémoires de l'Académie royale de médecine (Fig. 1).

In discussing the significance of the cortical stratification, BAILLARGER pointed out that gray and white layers alternated with one another, and he was able to establish by rather crude examination with a microscope that the gray layers were made up of cells while the white strips consisted of fiber projections.

In a second report he raised the question of whether intelligence among the mammals was to be correlated with the number of cortical layers and the extent of the convolutions. Thus he says ${ }^{5}$ : «Si l'on considère que les animaux les plus intelligents non seulement ont le cerveau le plus ondulé, mais qu'ils ont des circonvolutions qui leur sont propres; si l'on se rappelle la facilité avec laquelle apparaît le délire dans les inflammations des surfaces cérébrales, les altérations de la couche corticale dans la folie, surtout celles qu'elle offre dans la paralysie générale des aliénés qui s'accompagne d'une démence si profonde, l'atrophie des circonvolutions dans la démence, etc., on ne balancera pas à attribuer un rôle important aux surfaces cérébrales. La structure si compliquée de la couche corticale peut être invoquée comme un argument de plus.» This, then, constitutes the basis of BaILLARGER's organicist concept of mental disease-a concept which he continued to elaborate in the course of later life.

GeNNARI had seen the crude stratification of the occipital lobe and VICQ D'AzYr had described the occipital layers in greater detail; MEcKeL had disclosed the laminae of Ammon's horn, but it was BAILLARger who proved the existence of lamination throughout the convolutions of the entire cerebral cortex of all mammals which he had examined, including

${ }^{5}$ J. Soury, Le système nerveux central. Structure et fonctions. Histoire critique des théories et des doctrines. Paris, Georges Carré and C. Naud, 1899, p. 569/70. 
the human infant at birth, and it was thus he who first raised the question of the relation of this structural matrix to intelligence and to the elaboration of mental function in man and the higher animals. This he adumbrated at the age of thirty in his first published work. After that of GenNari, BaIllarger's work stands as the most important contribution to our knowledge of cerebral structure until the days of HAMMARBERG ${ }^{6}$, BRoDMANN $^{7}$, and the Vogts ${ }^{8}$.

BAILLARGER is very little known and seldom referred to in modern literature, but if one may gauge by the notices which appeared at the time of his death $^{9-12}$, he influenced not only French thought in the sphere of psychiatry, but the thought of all those in the nineteenth century who were concerned with the management of the mentally ill. The story of his life runs thus.

Jules-Gabriel-François Baillarger was born in the town of Montbazon (Indre-et-Loire) on 26 March 1809 and he died in Paris in his eightyfirst year on 31 December 1890. His medical studies were begun in the medical school at Tours, but it was from Paris that he obtained his medical degree in 1837. While preparing for his degree, BAILLARGER, beginning in November 1830, served as élève externe under the great French psychiatrist, Jean-Etienne Dominique Esquirol, at the Maison de Charenton, and it was Esquirol who aroused his interest in problems of mental derangement. Being a Frenchman of dee-running loyalties he retained through out his

${ }^{6}$ C. Hammarberg, Studien über Klinik und Pathologie der Idiotie nebst Untersuchungen über die normale Anatomie der Hirnrinde, Upsala, Akad. Buchdruckerei, 1895 (6), 128 p., $7 \mathrm{pl}$.

7 K. Brodmann, Beiträge zur histologischen Lokalisation der Großhirnrinde: I. Die Regio rolandica, J. Psychol. Neurol. Leipzig 2, 79-107 (1903); III. Die Rindenfelder der niederen Affen, ibid. 4, 177-226 (1905); V. Über den allgemeinen Bauplan des Cortex pallii bei den Mammaliern und zwei homologe Rindenfelder im besonderen, zugleich ein Beitrag zur Furchenlehre, ibid. 6, 275-400 (1906); VI. Die Cortexgliederung des Menschen, ibid. 10, 231-46 (1907). See also: Vergleichende Lokalisationslehre der Großhirnrinde in ihren Prinzipien dargestellt auf Grund des Zellenbaues, Leipzig, J.A.Barth, 1909; reprinted, 1925, xii, 324 p.

8 O. Vogt and CÉcile Vogt, Neurobiologische Arbeiten: I. Zur Erforschung der Hirnfaserung, 3 Bände, Jena, Gustav Fischer, 1902-1904. See also: Zur Kenntnis der elektrisch erregbaren Hirnrinden-Gebiete bei den Säugethieren, J. Psychol. Neurol. Leipzig 8, 277-456 (1907) and Ergebnisse unserer Hirnforschung, ibid. 25, 277-462 (1919).

${ }^{9}$ Brit. med. J. 1, 205 (1891).

10 J. ment. Sci. 37, 333 (1891).

11 Laborde, Trib. méd. Paris 24, 17-20 (1891).

${ }_{12}$ Amer. J. Insanity 47, $456 / 7$ (1891). 
life a profound admiration and affection for his master and years later when the Esquirol statue was dedicated, it was BaIllarger who pronounced the eloquent éloge in tribute to his former teacher and friend ${ }^{13}$.

In 1840, at the age of thirty-one, Baillarger was appointed Physician to the Salpêtrière, where for twenty years his clinical lectures attracted large audiences. In addition to this post, he was associated first with Esquirol and then with Moreau in the direction of the asylum at Ivry. He thus had ample opportunity to observe large numbers of patients and out of his conscientious and painstaking studies came the many contributions which he made to the field of psychiatry.

Throughout his life, Baillarger was an ardent supporter of and contributor to medical societies and journals, becoming a member of the Academy of Medicine in 1847 and its President in 1878. He founded the influential Société Médico-Psychologique and became the tireless editor of its chief organ, the Annales Medico-Psychologique, which he had founded in 1843. BAILLARGER was a prolific writer and his first memoir on the cortical layers, which was followed by two additional essays bearing upon the same subject $^{14,15}$ was only the first of many writings. For the second memoir he studied the development of the cortical layers and found that there was clear-cut stratification present by the end of the fifth month of gestation.

In the broad field of psychiatry, BaILLARger's contributions were original and in advance of his time. He was the first to recognize manic-depressive psychosis as a clinical entity, emphasizing the cyclical character of the disease ${ }^{16}$. He also devoted attention to the problem of hallucinations ${ }^{17}$, pointing out that such aberrations are in reality the result of psychological reactions to conflict-he referred to them as being "involuntary". This led him to consider the dreamy state which occurs between sleeping and waking, and he pointed out that most patients are prone to have their hallucinations during this intermediate period.

13 J.-G.-F. BAILLARGER, Eloge on Esquirol.

${ }^{14}$ J.-G.-F. Baillarger, Mémoire sur le mode de formation des centres nerveux, Paris, Baudoin, 1843. 16 p. Reprinted from Ann. med.-psych. Paris 2 (1843).

${ }^{15}$ J.-G.-F. Banllarger, De l'état désigné chez les aliénés sous le nom stupidité, Paris, Bourgogne \& Martinet, 1843, 52 p. Reprinted from Ann. méd.-psych. Paris 1 (1843).

16 J.-G.-F. BaILlARgER, Recherches sur les maladies mentales et sur quelques points d'anatomie du système nerveux, Paris, V. Masson, 1853. xxxvi, 424. p.

17 J.-G.-F. Batllarger, De l'influence de l'êtat intermédiaire à la veille et au sommeil sur la production et la marche des hallucinations, Paris, Bourgogne \& Martinet, 1845. 58 p. 
General paralysis, so-called, likewise engaged his attention ${ }^{18}$ and he distinguished two forms of the condition based on the presence or absence of mental symptoms. The fact that motor difficulties developed in the course of general paralysis led him to regard the disease as an organic malady quite distinct from "functional" mental disturbances in which the patients are without neurological deficit. His point of view regarding general paralysis was of course completely vindicated when its sphirochetal origin became established.

BAILLARger was thus one of the first great organicists in the field of psychiatry, and while he was disappointed in his early days not to be able to establish the existence of organic changes in the cortical layers in all seriously deranged patients, he never abandoned his conviction that mental derangement must have some subtle, morphological basis. His studies on mental changes in cretinism gave further evidence favouring the organic point of view.

His greatest over-all contribution lay in his classification of the neuroses and the major psychoses; this in turn was based upon the extraordinary clarity with which he defined his clinical syndromes such as the manic depressive psychosis and general paralysis. His most important papers on this general theme appeared in his own Annales Médico-Psychologique, but he also contributed a valuable appendix to the French translation of W. GrIEsinger's Traité des maladies mentales entitled, «Des symptomes de la paralysie générale et des rapports de cette maladie avec la folie», and published in Paris in $1873^{19}$.

All the notices of BAILLARger which appeared at the time of his death made note of his warm personal qualities. One anonymous tribute, published in the American Journal of Insanity, contained the following paragraph ${ }^{20}$ :

He was a man of great benevolence and charity, whose lofty altruism showed itself in countless benefactions, the source of which he sedulously concealed from the public. It is said that many of his gifts in charity were bestowed in the name of his grandchildren, to the end that they might be led to cultivate the humanitarian virtues. He took great interest in a

18 J.-G.-F. Baillarger, Essai de classification des maladies mentales; leçon faite à la Salpêtrière le 9 avril 1854, Paris, V. Masson, 1854. 44 p.

19 J.-G.-F. BaIllarger, Des symptomes de la paralysie générale et des rapports de cette maladie avec la folie, Appendix (p. 591-736) to W. GRIESINGER Traitê des maladies mentales; pathologie et thérapeutique, Paris, Adrien Delahaye, 1873.

${ }^{20}$ Obituary. Amer. J. Insanity 47, 457 (1891). 
society-and, indeed was its founder-to protect and provide for patients who had been discharged recovered from la Salpêtrière and Bicêtre, as well as in another looking to the succor of the "fatherless children and widows" of deceased alienists, by organizing and presiding over «l'Association mutuelle des médecins aliénistes de France». His devotion to the patients of la Salpêtrière is an imperishable memory, and especially are his courage and self-denial, as shown during the epidemic of cholera in 1849 , remembered at that institution.

A man of this stature, who made a fundamental contribution to neurophysiology, who did much to advance knowledge in the field of psychiatry, and who made a deep and lasting impression on the life of his generation deserves to be brought again to the attention of all those who are concerned with science and medicine and especially with psychiatry, for BAILLARGER's organic concepts are at long last coming into their own.

\section{Wachsplastik und ihre Museen}

\section{Von Edgar Goldschmid, Lausanne}

Vor etwa hundert Jahren sah sich JACOB GRImm bewogen, der zweiten Auflage seiner Geschichte der deutschen Sprache eine neue Vorrede mitzugeben, da ihm die vom Jahr 1848 nicht mehr recht zu den Zeitläuften von 1853 zu passen schien. Die Unruhen waren zu Ende, aber noch kein Frieden herrschte. Seine Beschäftigung mit Sprachgeschichte und seine «Gleichsetzung von Goten und Geten» schien nicht zeitgemäß. Was er nun hierzu verlautbart, glauben wir unserem Beitrag zur Festschrift für unseren Freund Sigerist zweckmäßig voranstellen zu dürfen.

Er sagt (p. VIII) : «Jede wissenschaft hat ihre natürlichen grenzen, die aber selten dem auge so einfach vorliegen, wie das stromgebiet des bachs, in dessen mitte nach unseren weisthümern ein schneidendes schwert gesteckt wird, damit das wasser zu beiden seiten abfließe. willige forscher sollen also den verschlungenen pfaden folgen und bald leichteres bald schwereres geschühe anlegen, um sie betreten zu können. Wer nichts wagt gewinnt nichts und man darf mitten unter dem greifen nach der neuen frucht auch den mut des fehlens haben. aus dem dunkel bricht das licht hervor und der vorschreitende tag pflegt sich auf seine zehen zu stellen. von der großen 